\title{
Trade Policy Evaluation on Rubber and Palm Oil
}

\author{
Kumara Jati \\ Trade Analysis and Development \\ Agency \\ Ministry of Trade of Republic of \\ Indonesia \\ Jakarta, Indonesia \\ kumara_jati@yahoo.com \\ Muhammad Fawaiq \\ Trade Analysis and Development \\ Agency \\ Ministry of Trade of Republic of \\ Indonesia \\ Jakarta, Indonesia \\ m.fawaiq@ kemendag.go.id
}

\author{
Wibowo Kurniawan \\ Trade Analysis and Development \\ Agency \\ Ministry of Trade of Republic of \\ Indonesia \\ Jakarta, Indonesia \\ halopopo@yahoo.com \\ Rino Adi Nugroho \\ Trade Analysis and Development \\ Agency \\ Ministry of Trade of Republic of \\ Indonesia \\ Jakarta, Indonesia \\ ran.kemendag@gmail.com
}

\author{
Arie Mardiansyah \\ Trade Analysis and Development \\ Agency \\ Ministry of Trade of Republic of \\ Indonesia \\ Jakarta, Indonesia \\ arie.mardiansyah@ymail.com
Deky Paryadi
Trade Analysis and Development Agency
Ministry of Trade of Republic of Indonesia
Jakarta, Indonesia
deckyparyadi@gmail.com

\begin{abstract}
Rubber and palm oil are the two main export commodities that contribute to economic development in Indonesia. Specific trade policy has to be implemented when export commodity prices fluctuating or increasing or decreasing rapidly in the short period of time. The research purpose is to write a trade policy evaluation on rubber and palm oil using ARMA-ARCH/GARCH and structural timeseries model. This study shows that price movement aspect is very important to evaluate the trade policy. The results of the analysis using Autoregressive and Moving Average and Autoregressive Conditional Heteroskedasticity/Generalized Autoregressive Conditional Heteroskedasticity (ARMAARCH/GARCH) indicate that past price factors can be used to predict future prices. The Structural Time-Series Model (STSM) shows that the price of rubber and palm oil in $\mathbf{2 0 2 0}$ and 2021 is expected to be relatively stable. The relevant trade authorities need to maximize the public services related to the price predictions and upcoming policy in order to maintain export stability in the short and long terms so that it can be utilized to the greatest extent possible for development of Indonesia.
\end{abstract}

Keywords-Trade Policy, Rubber and Palm Oil Price, ARMA-ARCH/GARCH, Structural Time-Series Model (STSM)

\section{INTRODUCTION}

Rubber and palm oil are Indonesia's main export commodities abroad. Both products are the countries leading foreign exchange earning commodities. Indonesia is one of the largest natural rubber and palm oil producing countries. These two commodities also absorbing lots of employees, especially in the villages, but unfortunately, in the past few years, rubber and palm oil price have tended to decrease.

In 2018, Rubber and rubber products is the 4th biggest Indonesian export commodity about 6.3 billion US\$ with HS code 40 and palm oil as a part of animal/vegetable fats and oil is the first biggest Indonesian export commodity about 20 billion US\$ with HS code 15 [1]. Both commodity export numbers have a tendency to decrease in 2018 compared with 2017, also in the period January-May 2019 compared with January-May 2018. The relevant authorities need to evaluate trade policy on the conditions that occur.
The urgency of this research paper that not many literatures evaluate the trade policy on rubber and palm oil. There is a space to fill a new point of view. Moreover, this research purpose is to write a trade policy evaluation on rubber and palm oil using ARMA-ARCH/GARCH and structural time-series model.

\section{METHODOLOGY}

A. AutoRegressive Moving Average-AutoRegressive Conditional Heteroskedasticity / Generalized AutoRegressive Conditional Heteroskedasticity (ARMAARCH /GARCH) Analysis

A simple Auto Regressive Moving Average analysis is ARMA $(1,1)$. ARMA is a basic univariate analysis done by a procedure of Box-Jenkins with 3 steps: (1). Identification by comparing and observing correlogram from the existing model's combination; (2) Maximum Likelihood (ML) and Ordinary Least Square (OLS) estimation; (3) evaluation to review the estimated model if it is sufficient.

$\mathrm{ARCH}$ is a model that analyzes a conditional variance. The assumption of OLS using BLUE assumptions (Best Linear Unbiased Estimator). The first ARCH/GARCH model was introduced and generalized by Engle (1982) and Taylor (1986) and Bollerslev (1986) [2] [3] [4].

\section{B. Structural Time-Series Model (STSM) Analysis}

Rubber and palm oil price are macroeconomic variables that fluctuate and is not easy to predict. So, a basic model is needed to analyze the changes and dynamics of these variables. A simple way is to get a better understanding to predict accurately and precisely based on an alternative model, namely Structural Time-Series Model (STSM) [5].

The advantages of Structural Time-Series Model Analysis from average calculations, which are more measurable, can show the pattern of trends, seasonal and cycles of the price of rubber and palm oil. The pattern can be explained as follows [6]: 
1) A component of Trends that follow a process of random walk:

$$
\begin{aligned}
& \tau_{t}=\mu_{t}+\tau_{t-1}+n_{t}, n_{t} \sim N\left(0, \sigma_{\eta}^{2}\right) \\
& \mu_{t}=\mu_{t-1}+v_{t} \sim N\left(0, \sigma_{v}^{2}\right)
\end{aligned}
$$

2) A component of Cycle with the specification of $\psi_{j, t}$ follows the model of trigonometric:

$\left[\begin{array}{l}\psi_{j, t} \\ \psi_{j, t}^{*}\end{array}\right]=\rho \psi\left[\begin{array}{cc}\cos \lambda_{c} & \sin \lambda_{c} \\ -\sin \lambda_{c} & \cos \lambda_{c}\end{array}\right]\left[\begin{array}{l}\psi_{j, t-1} \\ \psi_{j, t-1}^{*}\end{array}\right]+\left[\begin{array}{l}K_{t} \\ K_{t}^{*}\end{array}\right]$

for $\mathrm{t}=1, \ldots, \mathrm{T}$, where $\psi_{t}$ is a component of cycle, $\rho_{\psi}$ and $\lambda_{c}$ are frequency and damping factors with values $0<\rho_{\psi} \leq 1$ and $0 \leq$ $\lambda_{c} \leq \pi$ while $K_{t}$ and $K_{t}^{*}$ are not mutually correlated $N\left(0, \sigma_{k}{ }^{2}\right)$.

3) Component of Seasonal with the specification of $y_{t}$ follows the model of trigonometric, whose models resembles cycle component

$\left[\begin{array}{l}\gamma_{j, t} \\ \gamma_{j, t}^{*}\end{array}\right]=\left[\begin{array}{cc}\cos \lambda_{j} & \sin \lambda_{j} \\ -\sin \lambda_{j} & \cos \lambda_{j}\end{array}\right]\left[\begin{array}{c}\gamma_{j, t-1} \\ \gamma_{j, t-1}^{*}\end{array}\right]+\left[\begin{array}{c}\omega_{t} \\ \omega_{t}^{*}\end{array}\right]$

for $j=1, \ldots,[s / 2] ; \quad t=1, \ldots, T$, where $\gamma_{t}$ is a component of seasonal, $\omega_{t}$ is an error term of $\gamma_{t}$.

If all three components are summed then STSM becomes:

$$
y_{t}=\tau_{t}+\gamma_{t}+\psi_{t}+\varepsilon_{t}
$$

Therefore, $y_{t}$ is the price of the rubber and palm oil price predicted by the component of trend $\left(\mathrm{G}_{t}\right)$, cycle $\left(\psi_{t}\right)$, and seasonal $\left(\gamma_{t}\right)$, This model is estimated using the method of Maximum Likelihood Estimation (MLE) and estimate components generated from Kalman filter (Harvey \& Peters, 1993). The software used in this model is Ox-Metrics Stamp 7. The type of data is 282 monthly price data on the period of January 1996 to June 2019 for rubber, palm oil and palm kernel oil prices. The rubber price taken from several sources (Singapore exchange Ltd, Bloomberg, the Rubber Association of Singapore Commodity Exchange and World Bank) for Rubber (Asia) RSS3 grade on US\$ $/ \mathrm{kg}$. The palm oil price taken from Crude Palm Oil Futures end of day settlement price from CME Group on US\$ per metric ton. The palm kernel oil taken from World Bank (C.I.F Rotterdam from Malaysia) on US\$ per metric ton.

\section{RESULT AND DISCUSSION}

\section{A. ARMA-ARCH/GARCH Analysis}

Table I shows the monthly descriptive statistics of rubber, palm oil and palm kernel oil price year 1996 to 2019. All the skewness values are greater than zero indicates that the distribution is more to the right. The kurtosis value is greater than three for rubber and palm kernel oil price showed that the distribution square of this variable have a fat tail compared to normal distribution. This kurtosis value is higher than 3 also indicates of heteroscedasticity. Palm kernel oil price has mean price the highest compared to other commodities.
TABLE I. DESCRIPTIVE QUANTITATIVE ANALYSIS OF THE RUBBER, PALM OIL AND PALM KERNEL OIL PRICE

\begin{tabular}{cccc}
\hline & RUBBER & PALM_OIL & PALM_KERNEL_OIL \\
\hline Mean & 1.815674 & 645.8705 & 836.7642 \\
Median & 1.605000 & 609.9200 & 736.9200 \\
Maximum & 6.260000 & 1292.000 & 2296.000 \\
Minimum & 0.490000 & 234.0000 & 269.0000 \\
Std. Dev. & 1.085312 & 238.9731 & 363.4945 \\
Skewness & 1.323337 & 0.560263 & 1.031140 \\
Kurtosis & 4.941964 & 2.763754 & 4.191480 \\
Observations & 282 & 282 & 282 \\
\hline
\end{tabular}

\section{B. Stationarity Test Result}

TABLE II. STATIONERITY TEST USES AUGMENTED DICKYFULLER (ADF) RESULT

\begin{tabular}{ccccc}
\hline No. & Variable & $\begin{array}{c}\text { Test } \\
\text { ADF }\end{array}$ & $\begin{array}{c}\text { MacKinnon } \\
\text { Critical Value }\end{array}$ & Order Integration \\
\hline 1 & Rubber & -13.02 & $-3.45^{* * *}$ & 1 st difference \\
2 & Palm Oil & -11.26 & $-3.45^{* * *}$ & 1 st difference \\
3 & Palm Kernel & -6.76 & $-3.45^{* * *}$ & 1 st difference \\
& Oil & & \\
\hline \multicolumn{4}{c}{ Note: ${ }^{* * * * *, *}$ represents the levels of significance of $1 \%, 5 \%$, and $10 \%$, respectively } \\
\end{tabular}

Rubber and palm oil price were analyzed using Eviews econometric software. The stationarity data test should be performed before estimating ARCH/GARCH and STSM analysis. Time coherent data can be said to be stationary if the values of averages, variance and autocovariance for each lag are constant over time [7]. The way to detect the stationarity of an existing variable is by using Augmented Dicky-Fuller (ADF) test. This ADF test is done at the first difference (1st integration order).

\section{ARMA-ARCH/GARCH Analysis Result}

1) ARMA

TABLE III. THE BEST ARMA FOR ALL VARIABLES

\begin{tabular}{cll}
\hline No. & Variables & $\begin{array}{l}\text { The Best Model } \\
\text { for ARMA }\end{array}$ \\
\hline 1 & Rubber & AR(1) \\
2 & Palm Oil & MA(1) \\
3 & Palm Kernel Oil & MA(1) \\
\hline
\end{tabular}

Table III shows the best ARMA model for the variables varies. Rubber price is known to have Auto Regressive (AR) in the first order and palm oil and palm kernel oil are known to have Moving Average (MA) in the first order. The election of the first order is common in the ARMA model because if the order is taken higher (second or third order) then the effect will be smaller in the ARMA model. 


\section{2) Test Result of ARCH/GARCH}

This research paper uses ARCH/GARCH model based on ARMA model. The ARMA result indicates that the clustering volatility indicates an ARCH effect. Furthermore, data is tested whether no ARCH effect or not on the model then used ARCH-LM test.

TABLE IV. ARCH-LM TEST

\begin{tabular}{|c|c|c|c|}
\hline No. & Variables & $\begin{array}{l}\text { Obs*R- } \\
\text { squared } \\
\text { (LM } \\
\text { statistic) }\end{array}$ & $\begin{array}{c}\text { F-statistics } \\
\text { (Probability) }\end{array}$ \\
\hline 1 & Rubber (d_rubber c ar(1)) & 0.003586 & $\begin{array}{l}0.003561 \\
(0.9525)\end{array}$ \\
\hline 2 & $\begin{array}{c}\text { Palm Oil (d_palm_oil c } \\
\operatorname{ma}(1))\end{array}$ & 2.9709905 & $\begin{array}{l}2.981317 \\
(0.0853)^{*}\end{array}$ \\
\hline 3 & $\begin{array}{c}\text { Palm Kernel Oil } \\
\text { (d_palm_kernel_oil c } \\
\text { ma(1)) }\end{array}$ & 0.00109 & $\begin{array}{c}0.001082 \\
(0.9738)\end{array}$ \\
\hline
\end{tabular}

Table IV shows that only palm oil price variable that has a probability below $10 \%$ (significant). This indicates that ARMA will be more effective for rubber and palm kernel oil price variables and the ARMA-ARCH/GARCH model will be more effective to palm oil price that have probability below $10 \%$. Then, further estimate is to simulate the ARCH/GARCH test by estimating the parameters using Quasi Maximum Likelihood (QML). This estimation is to get the ARCH/GARCH model from the lowest value presented in Akaike Info Criterion (AIC) and Schwarz Criterion (SC) values.

Table $\mathrm{V}$ show that $\alpha$ is the ARCH coefficients and $\beta$ is the GARCH coefficient. This calculation takes the lowest values of AIC and SC. It also selected significant values of constants, $\alpha$ and $\beta$. Therefore, based on the simulation comparison of some models, it is seen that the best model chosen is D_Palm Oil-MA(1)-GARCH $(1,1)$ for palm oil prices. This indicates that the past price factors can be used to predict palm oil price in the future based on MA(1)-GARCH $(1,1)$ model.

TABLE V. TEST ARMA-GARCH(1,1) OF THE PALM OIL

\begin{tabular}{cc}
\hline Coefficient & $\begin{array}{c}\text { Palm Oil (D_Palm Oil- } \\
\text { MA(1)-GARCH(1,1)) }\end{array}$ \\
\hline Constant $(C)$ & $8.611236^{* * *}$ \\
ARCH $(\alpha)$ & $0.213526 * * *$ \\
GARCH $(\beta)$ & $0.561216^{* * * *}$ \\
AIC & 6.4004416 \\
SC & 6.465155 \\
\hline Note: ***,**,* represents the levels of significance of $1 \%, 5 \%$, and $10 \%$, respectively \\
Source: writer's calculation $(2019)$
\end{tabular}

\section{Analysis Result from Estimation of Structural Time- Series Model (STSM)}

1) Analysis Result from Estimation of Structural Time-Series Model (STSM)

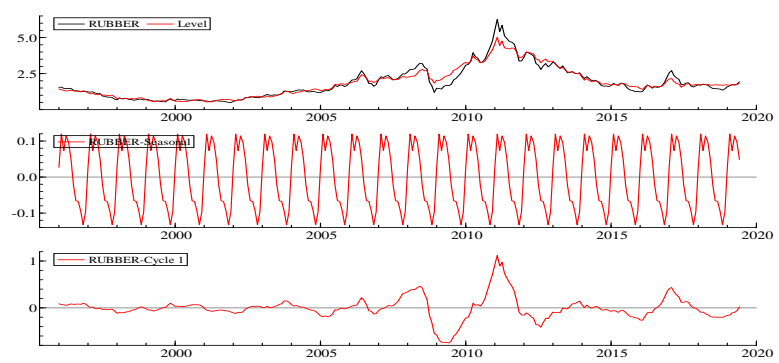

Source: Oxmetrices software calculation results (2019)

Fig. 1. Estimation of Rubber Price and the Influence of Trend, Seasonal and Cycle Components

STSM methodology to estimate the rubber price shows (see Figure 1): (1) rubber price trend derived from high seasonal and cycle components associated with supply and demand. Indonesia is one of the world's largest producers of natural rubber in addition to Malaysia and Thailand with its advantage in increasing rubber production for the future because of the availability of large tropical land [8]. Although, the rubber industry/price can no longer be viewed from the narrow point of view of a mere supplier of raw rubber [9]. (2) Seasonal component increased in the month of November-April, there were higher yields from rubber trees in the rainy season; seasonal component decreased in the month of May-October, there were lower yields from rubber trees in the dry season [10]. (3) The cycle component that decreased in the year 2009 happened because the total consumption of rubber (natural and synthetic) decreased significantly from 22,360 thousand tons in 2008 to 20,517 thousand tons in 2009 [11]; then the cycle component that increased in the year 2010 due to the fact that the consumption of rubber (natural and synthetic) increased to 24,017 thousand tons in 2010 [11].

Estimation of the rubber price from July 2019 to October 2021 will be decreased by $7.50 \%$. This is due to the fact that there may be a small surplus of natural rubber in the market for the next few years and short of demand. This can be happened if the external factors do not become a major factor in exchange rate irregularities [12]. In addition, other macroeconomic indicators such as exchange rate and oil price and other macroeconomic indicators should be well maintained. The result of Coefficient of Variation (CV) calculation from rubber is 5.57. This shows that the rubber price movements from July 2019 to October 2021 is estimated to decrease with a stable tendency because it is still below the $9 \%$ threshold. 
TABLE VI. ESTIMATION OF RUBBER PRICE

\begin{tabular}{|c|c|}
\begin{tabular}{|c|c|}
\hline Changes July 2019-October 2021 & -7.5 \\
\hline Coefficient of Variation (CV) & 5.57 \\
\hline
\end{tabular} \\
$\begin{array}{c}\text { Coefficient of Variation (CV) is the standard deviation divided by average, if below a value of } 9 \text { is } \\
\text { stable. }\end{array}$ \\
Source: Singapore exchange Ltd, Bloomberg, Rubber Association of Singapore Commodity \\
S
\end{tabular}

2) Estimation of Palm Oil with STSM Decomposition

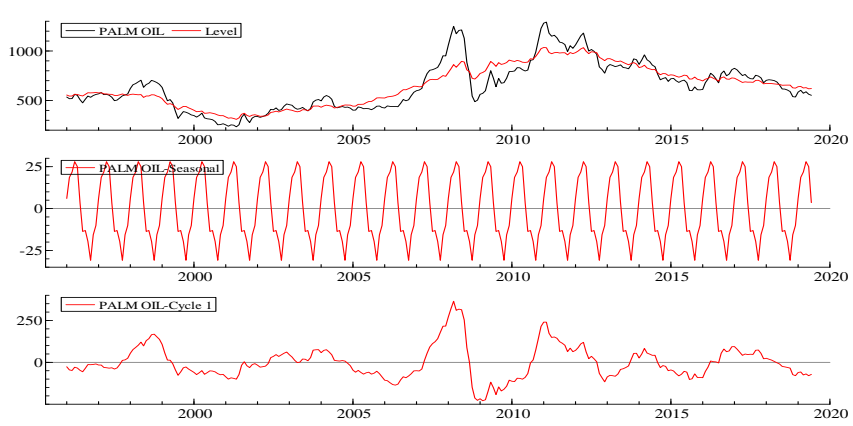

Source: Oxmetrices software calculation results (2019) Fig. 2. Estimation of Palm Oil and Influence of Trend, Cycle, and Seasonal Components

STSM methodology to estimates the palm oil shows (see Figure 2): (1) Dynamics of palm oil trend are derived from components associated with supply and demand of palm oil in the world economy over time. (2) Seasonal component of palm oil price increased from November until February when the CPO production starts to decline due to the monsoon rains; the seasonal component start to decrease from March until August in the moderate harvest season, while peak season in September or October every year [13]. (3) Different with seasonal, cycle in palm oil is relatively difficult to be estimated because of the pattern unstable and fluctuate from 2007 until now. The results of the STSM analysis to estimate the palm kernel oil is similar to the palm oil, the difference is the cycle in palm kernel oil pattern unstable and fluctuated from 2008 until now.

TABLE VII. ESTIMATION OF PALM OIL AND PALM KERNEL OIL

\begin{tabular}{|c|c|c|}
\hline Calculations & Palm Oil & Palm Kernel Oil \\
\hline $\begin{array}{c}\text { Changes July } \\
\text { 2019-October } \\
2021\end{array}$ & 10.34 & -2.1 \\
\hline $\begin{array}{c}\text { Coefficient of } \\
\text { Variation (CV) }\end{array}$ & 6.69 & 7.65 \\
\hline
\end{tabular}

Source: Crude Palm Oil Futures and CME Group

Estimation of the palm oil price from July 2019 to October 2021 will be increased by $10.34 \%$. This result is similar with the estimation from Malaysia Palm Oil Board (MPOB) and World Bank that the palm oil price will be increased at the end of 2019, 2020 and 2021[14] [15]. The Coefficient of Variation (CV) calculation result is 6.69. This number indicates that the palm oil price is estimated to stable due to the number is lower than the $9 \%$ threshold. The estimation of palm kernel oil prices from July 2019 to October 2021 will be decreased by $2.1 \%$ due to the fact that the production of Palm Kernel Oil forecast in 2018/2019 will be increased $3.4 \%$ compared to $2017 / 18$ [16].

\section{CONCLUSIONS AND POLICY RECOMMENDATION}

Based on ARMA-ARCH/GARCH analysis can be seen that the past price factors can be used to predict palm oil price in the future on $\operatorname{MA}(1)-\operatorname{GARCH}(1,1)$ model, but for rubber price and palm kernel oil price will be more effective to be estimated with ARMA. Then, the STSM methodology shows that: (1) rubber price trend derived from high seasonal and cycle components associated with supply and demand, (2) seasonal component of rubber price increased in the month of November-April where higher yields from rubber trees in the rainy season happened. The estimation of rubber prices from July 2019 to October 2021 will be decreased by $7.5 \%$ due to the fact that a small surplus of natural rubber in the world market and short of demand.

The STSM analysis shows that a seasonal component of palm oil price increased from November to February when CPO production starts to decline due to the monsoon rains. Although, it is difficult to estimate the seasonal of palm oil price because the unstable and fluctuate from the year 2007 until now. The estimation of palm oil price from July 2019 to October 2021 will be increased by $10.3 \%$ (similar forecast with the Malaysia Palm Oil Board and World Bank). Even though, the estimation of palm kernel oil prices from July 2019 to October 2021 will be decrease $2.1 \%$ because of the forecast of production will be increased $3.4 \%$.

It is necessary for the relevant authorities of trade to give more public information and services related to the estimation of price and future policy to give the symmetric information so that exist export stability in the short and long run. The benefit of this trade policy evaluation can be utilized by the farmers, traders, exporters and other business entities for the development of Indonesia.

\section{ACKNOWLEDGMENT}

On this occasion, the researcher would like to thank the Head of Trade Analysis and Development Agency, Secretary of Trade Analysis and Development Agency, Director of International Trade Cooperation Research Center, as well as a research and development team at the International Trade Cooperation Research Center-Ministry of Trade. In addition, the researchers also want to give credit to the relevant partners of the Ministry of Trade of The Republic of Indonesia who have provided assistance in the form of available information and data.

\section{REFERENCES}

[1] BPS, "Perkembangan Ekspor Non-Migas (Komoditi) Periode: 20142019", data dari Badan Pusat Statistik diolah Kementerian Perdagangan, retrieved 21 July 2019 from https://www.kemendag.go.id/id/economic-profile/indonesia-exportimport/growth-of-non-oil-and-gas-export-commodity.

[2] Engle, R.F., "Autoregressive Conditional Heteroskedasticity with Estimates of U.K. Inflation", Econometrica 64, 813-836, 1982.

[3] Taylor, S., "Modelling Financial Time Series", New York, John Wiley \& Sons, 1986.

[4] Bollerslev, T., "Generalized Autoregressive Conditional Heteroskedasticiy”, Journal of Econometrics, 31(3), 307-327,1986.

[5] Harvey, A., \& Peters, S., "Estimation procedures for structural time series models", Journal of Forecasting, 9(2), 89-108. https://doi.org/10.1002/for.3980090203, 1990. 
[6] Durbin, J., \& Koopman, S. J., "Time Series Analysis by State Space Methods",

https://doi.org/10.1093/acprof:oso/9780199641178.001.0001, 2001.

[7] Gujarati, D. N., "Basic Econometric: Fourth Edition International Edition”, Singapore: McGraw-Hill Higher Education, 2003.

[8] T. Novianti, dan E.H. Hendratno, "Analisis Penawaran Ekspor Karet Alam Indonesia ke Negara Cina”, Jurnal Manajemen Agribisnis, Vol.5, No.1 Maret 2008: 40-51, 2008.

9] M.F. Basri, M.S. Hapka., M.N., Jaafar., and A.A. Muhamat., "Determinants of the Price of Natural Rubber in Malaysia", International Journal of Business \& Management, ISSN 2321-8916, Vol. 6, Issue 12, December, 2018.

[10] Mohammad, Rondhi., "Effect of Improved Technologies on Income of Smallholder Rubber Farmers in Indonesia", Theses Doctoral, Hokkaido University, Collection of Scholarly and Academic Papers, HUSCAP,Japan, March 25, 2015.

[11] K.V. Raju., "Instability in Natural Rubber Prices in India: An Empirical Analysis", IOSR Journal of Economics and Finance (IOSRJEF), Volume 7, Issue 3, Ver.III (May-Jun 2016), pp 24-28.

[12] Economictimes, "Natural Rubber Supply will be Short of Demand from 2020, says ANRPC Secretary General”, News, Economic Times India Times.com; Retrieved July 22, 2019 from https://economictimes.indiatimes.com/news/economy/agriculture/natu ral-rubber-supply-will-be-short-of-demand-from-2020-says-anrpcsecretary-general/articleshow/54899753.cms?from $=$ mdr.

[13] A.K. A. Rahman., N. Balu., F. M. Shariff., "Impact of Palm Oil Supply and Demand on Palm Oil Price Behaviour", Oil Palm Industry Economic Journal, Vol. 13 (1)/March 2013.

[14] World Bank, "World Bank Commodities Price Forecast", Publication Documents, World Bank, Retrieved July 22, 2019 from http://pubdocs.worldbank.org/en/598821555973008624/CMO-April2019-Forecasts.pdf

[15] MPOB, "Global Palm Oil Trade-Prospects and Outlook", Research Report Malaysia Palm Oil Board (MPOB), Government of Malaysia, $\begin{array}{llll}\text { Retrieved July } & 22, & 2019 & \text { from }\end{array}$ http://www.mpob.gov.my/images/stories/pdf/2019/2019_1Palm\%20O il\%20Global\%20Trade.pdf.

[16] USDA, "Malaysia Oilseeds and Products Annual 2018", Report of United States Department of Agriculture (USDA) Foreign Agriculture Service, 4/11/2018, Retrieved July 22, 2019 from http://agriexchange.apeda.gov.in/MarketReport/Reports/Oilseeds_and _Products_Annual_Kuala_Lumpur_Malaysia_4-11-2018.pdf. 